\title{
Separation and Culturing of Stem Cells from the Gastric Mucosa of the Adult Male Albino Rats
}

\author{
MOHAMED ABDEL RAHMAN, M.D.; HANAA A. ABDEL NAEIM MOHAMMED, M.D. and \\ SAFAA M. EL-MAHDY, M.D. \\ The Department of Human Anatomy \& Embryology, Faculty of Medicine, Sohag University, Egypt
}

\begin{abstract}
Background: Gastric stem cells (GSCs) can be isolated from the mucosa of the stomach. They are multipotent stem cells having the ability to proliferate and differentiate into numerous cell lineages when cultured on suitable media. The ability of the gastric stem cells to proliferate and differentiate gives a hope for their potential use in the future as a line for cell therapy.
\end{abstract}

Aim of Study: This study was carried out to isolate GSCs from the mucosa of the stomach of the adult male albino rats, culture these GSCs in suitable medium to allow for their proliferation and characterization.

Material and Methods: The GSCs were isolated from the rat stomach, cultured in a suitable medium for proliferation then characterized and identified morphologically and immunohistochemically.

Results: The GSCs were isolated from the rats' stomach, proliferate in Fetal bovine serum (FBS) enriched DMEM F12 media with antibiotics to prevent the bacterial and fungal growth and proliferation. The GSCs were identified morphologically by the presence of long cytoplasmic processes and the formation of colonies. They were identified immunohistochemically by their positivity for CD44 and Nestin antigens and negativity against CD34 antigen.

Conclusion: The GSCs can be easily isolated from the stomach of rats, cultured in DMEM F-12 medium with $10 \%$ FBS to proliferate rapidly forming large colonies.

Key Words: Stomach - Gastric stem cells - Rats - Isolation - Culture.

\section{Introduction}

THE human body consists of more than two hundred of the cell types that form the different body tissues and organs [1]. All the cells are derived from a single totipotent cell that is the zygot that has all characters required for its viability and reproduction [2]. Stem cells are immature cells

Correspondence to: Dr. Mohammed Abdel Rahman, The Department of Human Anatomy \& Embryology, Faculty of Medicine, Sohag University, Egypt derived from the three germ layers of the embryonic disc (Ectoderm, endoderm and mesoderm) and present in the different body tissues with prolonged regeneration and multiplication capacity to replace the damaged daughter cells and, according to their origin, they can differentiate into multiple cell types or even all cell types of the body [3]. They can be artificially grown and transformed into specialized cell types and show the criteria of different cell types such as muscular, epithelial, liver and nerve cells [4].

The stem cells can also fix into damaged tissues to replace the damaged cells providing new hopes for treatment of different chronic diseases such as paralysis, Alzheimer disease and gastric peptic ulcer. In recent years, many researchers studied how to isolate, culture and proliferate the stem cells from numerous human and animal tissues including the epithelium of the gastrointestinal tract. These previous studies proved the ability of the stem cells to proliferate and differentiate when cultured on suitable media. Then, these cells can potentially be used in the curative treatment of some diseases [5].

The stem cells undergo two types of cell division; symmetrical and asymmetrical divisions. In the symmetric division, the stem cell divides into two identical daughter cells both of which have the properties of the stem cell. In the asymmetric division, the stem cell divides into (a) One stem cell that replaces its mother cell and undergoes more divisions and (b) A progenitor cell that undergoes more differentiation to give a mature functioning cell $[6,7]$.

Types of stem cells:

A- Embryonic stem cells (ESCs): They are pluripotent stem cells derived from the inner cell mass of the blastocyst and can differentiate into 
all cell types giving a good hope for cellreplacement therapies but with ethical problems [8].

B- Adult stem cells (Somatic stem cells): They are undifferentiated cells, found in all body tissues, they proliferate and divide continuously to replenish the dying cells and repaire the damaged tissues so, they can potentially divide to regenerate the entire organ from a few cells. Unlike the embryonic stem cells, the use of the human adult stem cells has no ethical problems, so can be used easily in research and therapy, as they are derived from adult body tissues not from the embryonic cell mass [9]. There are many types of the adult stem cells that include:

1- Neural stem cells (NSCs): Found in the central nervous system [10].

2- Mesenchymal stem cells (MSCs): In numerous tissues such as the lungs, wall of GIT, bone marrow blood, olfactory mucosa and the umbilical cord. They are an interesting source for potential cellular therapy as they have good plasticity, self-renewing ability and possibility of their cellular transplant. Also they have the possibility to differentiate to other specific cell types according to the culture conditions and environment in damaged tissue area because the resident cells lead MSCs to differentiate to replace the damaged cells [11].

3- Mammary stem cells: Isolated from the human and animal mammary gland [12].

4- Testicular stem cells (TSCs): Derived from the spermatogonia and give hope for restoration of the fertility of the infertile males [13].

5- Hematopoietic stem cells: In the bone marrow and umbilical cord blood and give all the blood cells [14].

C- Induced pluripotent stem cells (IPSCs): They are adult stem cells reprogrammed in vitro to gain the ability to give rise to all body tissues [15].

D- Fetal stem cells: In the organs of the fetus [16].

The stomach is a muscular hollow part of the gastrointestinal tract between the esophagus and the small intestine. Its functions include storage of food, digestion and acting as a chemical breakdown by means of enzymes and hydrochloric acid. Anatomically, the stomach consists anatomically of four parts from proximal to distal; cardia, fundus, body and pylorus that consists of pyloric antrum that is the dilated proximal part, pyloric canal that is a cylindrical part and pyloric orifice that is surrounded by the pyloric sphincter [17].
Histologically, the wall of the stomach consists of five layers from superficial to deep; mucosa that is the innermost layer, submucosa, musculosa, subserosa and serosa. The gastric mucosa, consists of a simple columnar epithelium, lamina propria of connective tissue and muscularis mucosa of smooth muscle fibers [18].

The gastric stem cells are present in the epithelium and lamina propria of the mucosa of the stomach. The epithelium of the stomach undergoes continuous regeneration from the epithelial stem cells throughout life to replace the damaged cells $[19,20]$.

\section{Material and Methods}

A- Site of this study: This experimental study was carried out in

1- The rats were purchased from and dissected in the Medical Research Center, Faculty of Medicine, Ain Shams University, Cairo.

2- The isolation and culturing of the gastric stem cells were carried out in the Pancreatic research center, Faculty of Medicine, Ain Shams University, Cairo.

B- Time of the study: From March to May 2021.

C- Equipment for cell culture:

1- Petri-dishes, flasks and disposable one use pipettes were used for culturing and subculturing the gastric stem cells and preparation and storage of the growth medium. They were transparent, biologically inert and nontoxic. All the instruments were sterilized by dry heat in the oven at about $160^{\circ} \mathrm{C}$ for one hour [21].

2- Laminar flow cabinet (NUAIRE, Biological Safety Cabinets Class II Type, USA) [22].

3- Standard air/ $\mathrm{CO}_{2}$ incubator (NUAIRE CF Autoflow $\mathrm{CO}_{2}$ Water jacketed Incubator, USA) [22].

4- Water bath (Polyscience) [23].

D- Reagents for cells extraction, culture and differentiation:

- Dulbecco's Modified Eagle's Medium with Ham's F12 (DMEM-F12) was used as a culture medium for proliferation of the gastric stem cells (Dulbecco's Modified Eagle's Medium with $4.5 \mathrm{~g} / \mathrm{L}$ Glucose, with L Glutamine, Cat. N: BE 12-604 F, Lonza. B 4800 Verviers, Belginum). It was stored at $4^{\circ} \mathrm{C}$ [24].

- Human platelet lysate: Was added to the culture medium as a nutrient for the actively dividing stem cells. It was stored at $70^{\circ} \mathrm{C}[25]$. 
- Antibiotics: 10.000u penicillin/ml and $10.000 \mathrm{u}$ streptomycin $/ \mathrm{ml}$ were added to the culture medium to prevent the growth of the bacteria and fungi [26].

- Trypsin/EDTA: $0.25 \%$ trypsin suspended in $0.05 \%$ Disodium ethylene diamine tetra-acetate). Helped the cells to get separate from each other and from the floor of the culture [27].

- Phosphate buffered saline (PBS): Was used as a sterile solution for washing [28].

\section{E- Reagents for immunohistochemistry:}

Monoclonal antibodies against the antigens CD34, CD44 [29] and nestin [30] (Sigma) were used to identify the GSCs.

\section{F- Microscopes:}

1- Light microscope (Nikon with Panasonic camera, Japan).

2- Inverted phase contrast microscope (Olympus BX 50 with premiere 88-500 digital camera, Japan).

\section{G- Isolation technique of the stem cells from the gastric mucosa:}

The isolation process was carried out under stricktly sterile conditions using a laminar flow hood, sterile gloves, overhead covers and masks to avoid any contamination.

Ten adult male albino rats of 6 months' age and 200-250 grams weight each were purchazed from and dissected in the medical research center, faculty of Medicine, Ain Shams University under sterile conditions then, the mucosa of the stomach was harvested and separated into small pieces then incubated in sterile falcon tubes with $0.1 \%$ collagenase type I for half an hour at $37^{\circ} \mathrm{C}$ when transmitted to the pancreatic research center, faculty of Medicine, Ain Shams University. Then these small pieces were separated into separate cells by centrifuging them for 10 minutes at $2000 \mathrm{rpm}$ then allowed to precipitate [31].

\section{H- Primary culturing technique of the gastric stem cells:}

The precipitates were cultured in petri-dishes containing $10 \mathrm{ml}$ complete medium that consists of Dulbecco's Modified Eagle's Medium with Ham's F12 (DMEM-F12) [24] enriched with human platelet lysate that is a nutrient for the dividing stem cells [27] with addition of $1 \%$ penicillin/streptomycin to prevent the bacterial growth [26]. The cells were incubated in a humidified atmosphere containing
$5 \% \mathrm{CO}_{2}$, at $37^{\circ} \mathrm{C}$. Three days later, the the culture medium with the non-adherent cells were removed and replaced by $10 \mathrm{ml}$ of a fresh complete medium. The culture was viewed daily and the medium was changed every 3 days to provide more nutrient and to remove the waste products. After 12-15 days, the cells became more than $80 \%$ confluent and the colonies were evidently formed then the cells were passaged into subcultures [32].

\section{I- Sub-culturing technique:}

The culture medium was removed by pipette aspiration then the cultured cells were immersed and washed in $10 \mathrm{ml}$ PBS for 3 times. Then the PBS was removed and $1 \mathrm{ml}$ of trypsin-EDTA was added to each Petri-dish to allow the cells to separate from the floor of the culture. The dishes were incubated in the $\mathrm{CO}_{2}$ incubator at $37^{\circ} \mathrm{C}$. The Petridishes were viewed every 5 minutes by the inverted microscope to detect the detached cells (The detatched cells were rounded and floating) and when the cells started to be detached from the floor, the dishes were shaken gently to accelerate the detatchement [33]. When all the cells were detached, $5 \mathrm{ml}$ of complete medium was added to the culture to alleviate and counteract trypsin-EDTA activity. Then, the cells were subcultured by dividing the solution in Petri-dishes (One $\mathrm{ml}$ in each dish) then $10 \mathrm{ml}$ of a fresh complete medium were added for each dish. The subcultures were incubated, monitored and followed-up as the same as the primary culture [34].

\section{J- Viability testing:}

The viable and dead cells were differentiated at the beginning and the end of the culture by the use of the vital stain trypan blue that stains the dead cells only. The gastric stem cells were detatched from the floor of the culture using trypsin EDTA then, a cell suspension was prepared in a complete medium, 89\% DMEM-F12 with 10\% FBS and $1 \%$ penicillin/streptomycin. $100 \mu 1$ of a solution of $0.4 \%$ trypan blue was added to $100 \mu 1$ of the cell suspension in a test tube and left for 2 minutes then viewed by the flow cytometry. The viable cells appeared as bright transparent circles while the dead cells appeared blue in color with irregular contour [35].

\section{$\mathrm{K}-$ Characterization of the gastric stem cells:}

Characterization of the gastric stem cells was performed by using immunocytochemical monoclonal antibodies against surface antigens on the rat gastric stem cells, these antigens are CD34, CD44 [29] and Nestin [30]. 
The gastric stem cells were fixed to the floor of the petri dishes by chilled acetone: Methanol (1:1) for ten minutes then the acetone and methanol were washed by phosphate buffer saline. The sections then were treated by $0.3 \%$ hydrogen peroxide in methanol for thirty minutes. The cells then incubated with CD34, CD44 [29] and nestin [30] monoclonal antibodies at room temperature for thirty minutes then examined by the phase contrast microscope.

\section{Results}

The gastric stem cells were isolated from the mucosae of the stomach of ten adult male albino rats then, the GSCs were cultured on suitable medium to allow them to proliferate.

\section{A- Viability assay:}

Statistical analysis of the viable and dead gastric stem cells showed a viability of $95.4 \pm 2.3 \%$ through all passages with statistically significant $p$-value $(p<0.5)$ (Fig. 1).

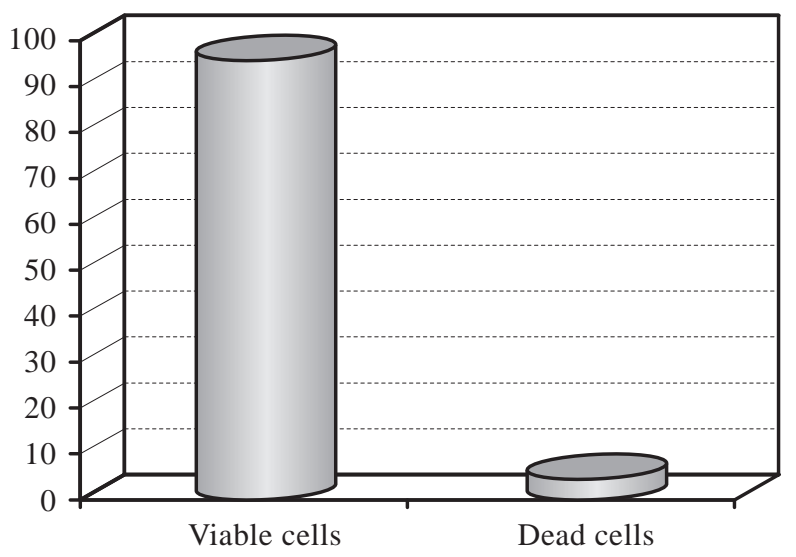

Fig. (1): Percentage of viable GSCs from the gastric mucosa of 10 male albino rats.

\section{B- The primary culture of the GSCs:}

In the primary culture, the GSCs became spindle shaped, with single nucleus and small processes and adhered to the dish floor after 3 daysn (Fig. 2). The non-adherent cells were removed. Three days later, the cells proliferate with elongation of their cytoplasmic processes (Fig. 3). Three days more later, more proliferation occurred reaching about $50 \%$ confluency and colonies appeared (Fig. 4).

At the end of the $2^{\text {nd }}$ week after plating and with continuous proliferation, the cultured cells reached more than $80 \%$ of the full confluency (Fig. 5).

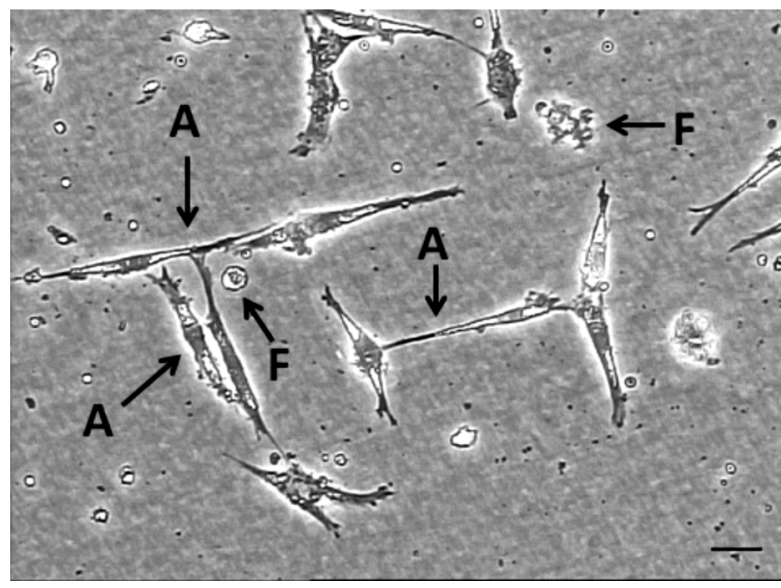

Fig. (2): A phase contrast photomicrograph of the primary cultured GSCs 3 days after seeding before wash. Numerous attached cells with cytoplasmic processes (A) and few floating cells (F). Scale bar $100 \mu \mathrm{m}$. X100.

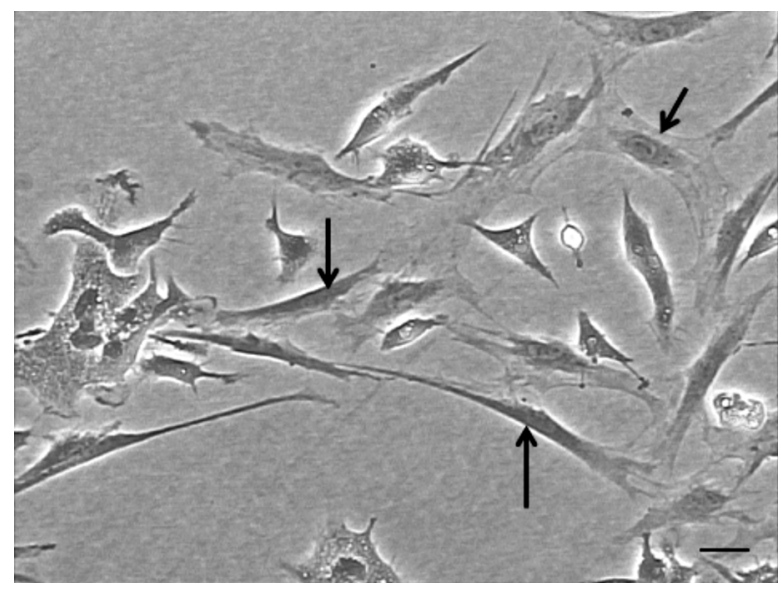

Fig. (3): A phase contrast photomicrograph of the primary cultured GSCs six days after seeding showing proliferation of the GSCs (Arrows). Scale bar $100 \mu \mathrm{m}$. X100.

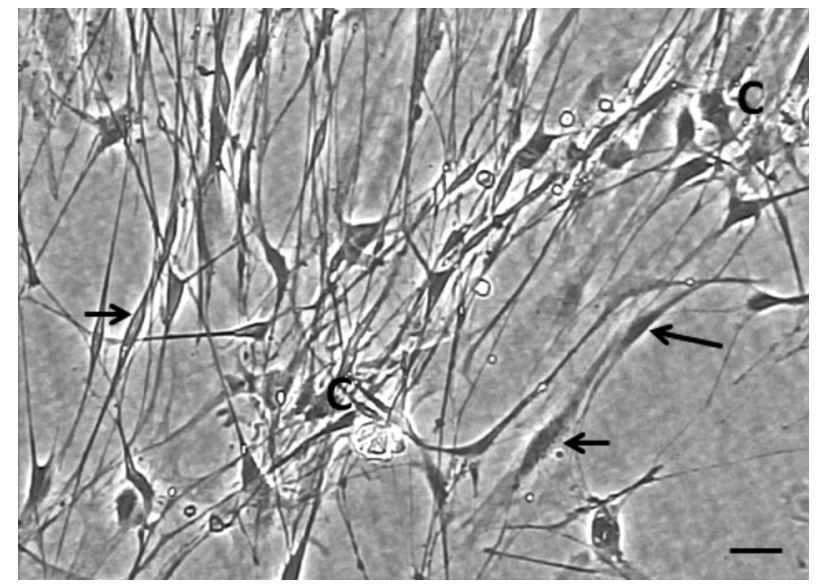

Fig. (4): A phase contrast photomicrograph of the primary cultured GSCs nine days after seeding showing proliferation of the GSCs (Arrows) with the presence of cell colonies (C) and about 50\% conflouency. Scale bar $100 \mu \mathrm{m}$. X100. 


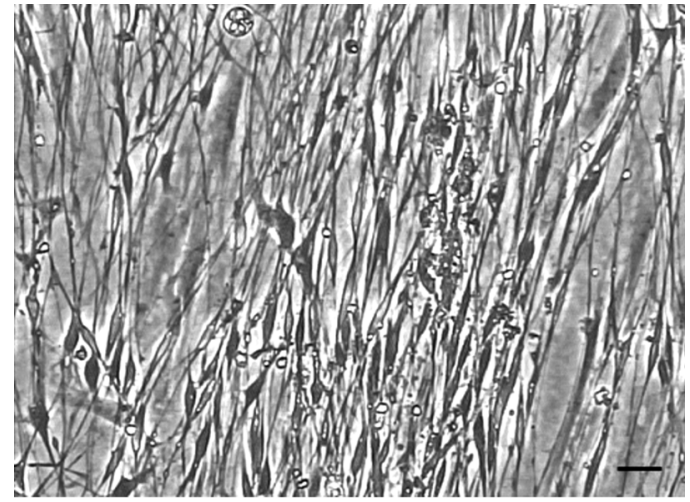

Fig. (5): A phase contrast photomicrograph of the primary cultured GSCs two weeks after seeding showing more proliferation of the GSCs with more than $80 \%$ conflouency. Scale bar $100 \mu \mathrm{m}$. X100.

\section{C- The subcultures of the GSCs.:}

In the subcultures, the GSCs were polygonal or spindle in shape, with numerous cytoplasmic processes in the first (Fig. 6), second (Fig. 7) and third passages (Fig. 8). The samples from all the ten rats showed the uniformity in colony formation and cellular shape.

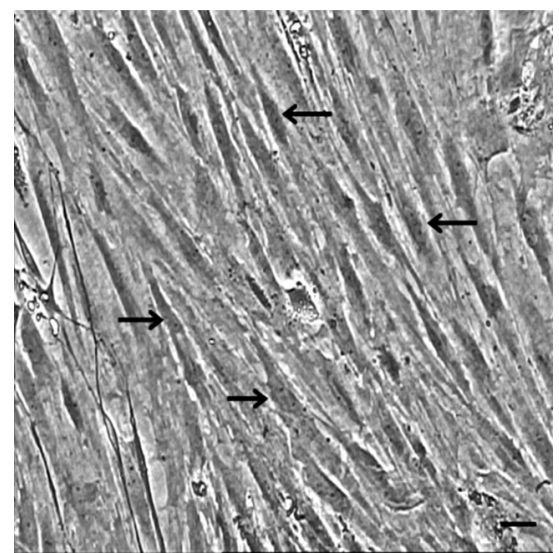

Fig. (6): A phase contrast photomicrograph of the cultured GSCs during the first passage showing polygonal cells (Arrows) with cytoplasmic processes and $100 \%$ confluency. Scale bar $100 \mu \mathrm{m}$. X100.

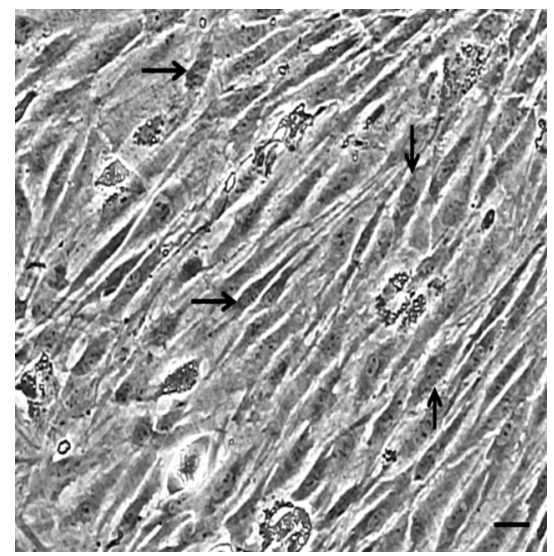

Fig. (7): A phase contrast photomicrograph of the cultured GSCs during the second passage showing polygonal cells (Arrows) with cytoplasmic processes and about $100 \%$ confluency. Scale bar $100 \mu \mathrm{m}$. X100.

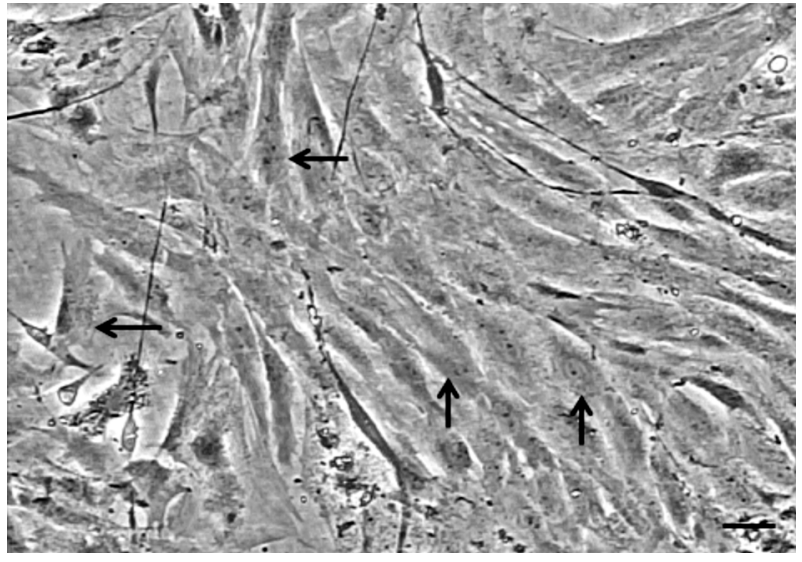

Fig. (8): A phase contrast photomicrograph of the cultured GSCs during the second passage showing polygonal cells (Arrows) with cytoplasmic processes with more than $90 \%$ confluency. Scale bar $100 \mu \mathrm{m}$. X100.

\section{D- The GSCs stained by Giemsa stain:}

When stained with Giemsa stain, the GSCs were polygonal with granular cytoplasm and central round nuclei (Fig. 9).

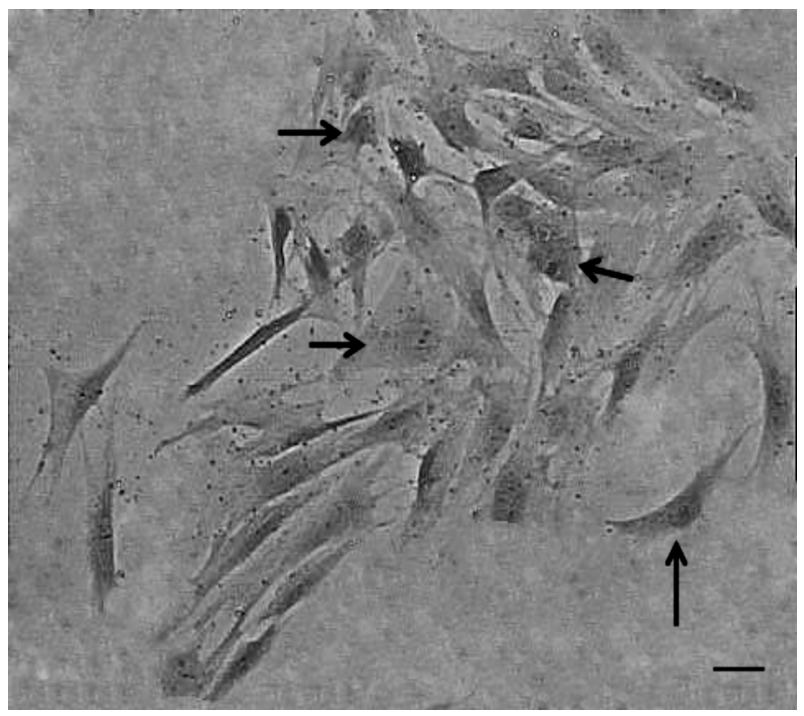

Fig. (9): A photomicrograph of the GSCs stained with Giemsa during the third passage. The cells have single nuclei and granular cytoplasm. Scale bar $100 \mu \mathrm{m}$. X 100.

E- Characterization of the rat gastric stem cells:

The gastric stem cells were identified immunohistochemically during the $3^{\text {rd }}$ passage by using monoclonal antibodies against rat antigents CD34, CD44, and Nestin. They were positive for CD44 (Fig. 10) and Nestin (Fig. 11) in the form of brown cytoplasmic staining. The GSCs were negative for CD34 (Fig. 12). 


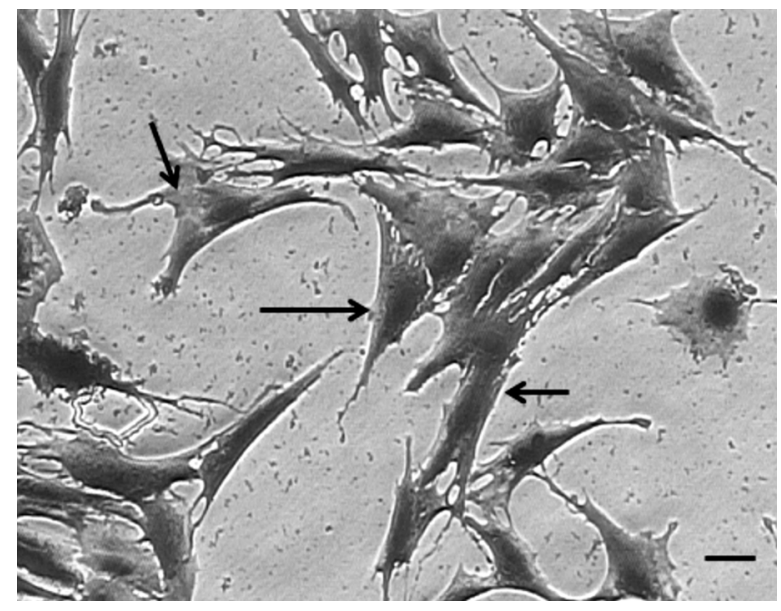

Fig. (10): A photomicrograph of GSCs during the third passage with immunostaining against the antigen CD44. The cells are positively brown stained. Scale bar $100 \mu \mathrm{m}$. X100.

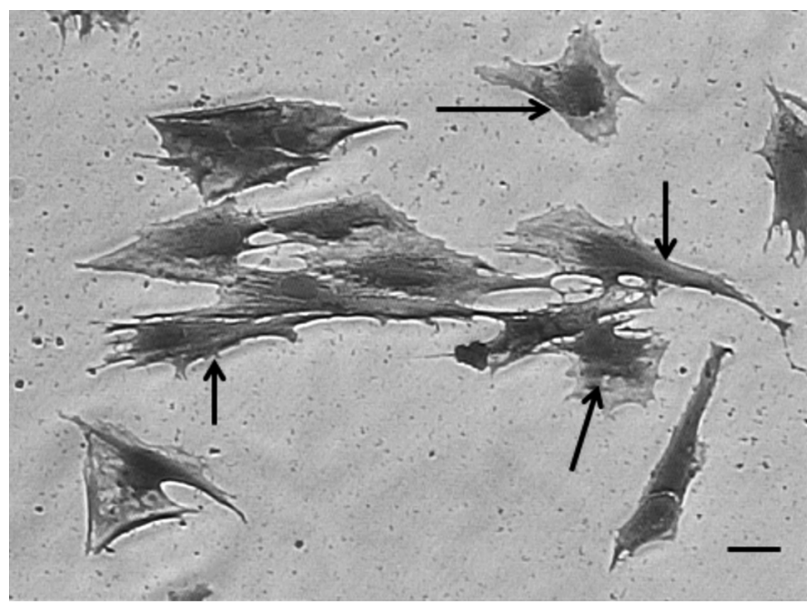

Fig. (11): A photomicrograph of GSCs during the third passage with immunostaining against the antigen nestin. The cells are positively brown stained. Scale bar $100 \mu \mathrm{m}$. X 100

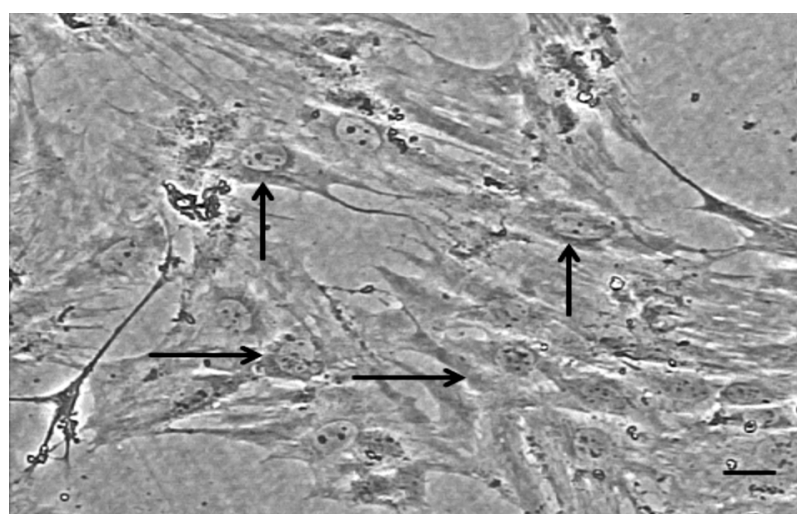

Fig. (12): A photomicrograph of GSCs during the third passage with immunostaining against the antigen CD34. The cells are negatively sained for CD34. Scale bar $100 \mu \mathrm{m} . \mathrm{X} 100$.

\section{Discussion}

This study revealed the possibility to isolate, proliferate and characterize the gastric stem cells from the mucosa of the stomach of the adult male albino rats. This was in correlation with the results of previous studies where the GSCs have been separated from the epithelium of the stomach of the human and cultured successfully the GSCs to study their response to the infection with helicobacter pylori [36]. Also, the GSCs have been previously described as rapidly proliferating cells [37] and this was confirmed in our study where full confluency of the GSCs in the culture was reached in two weeks.

The GSCs were identified in this study through their positivity for Nestin gene and this was in agrement with the previous study done by previous studies that studied the correlation between the overexpression of the antigen nestin on the gastric epithelium and the development of adenocarcinoma of the stomach depending on the normal presence of nestin as a protein antigen on the surface of the epithelial cells of the stomach [38]. Also the positivity of the GSCs in this study against CD44 is in correlation with the results of a previous sudy detected that the GSCs are positive for CD44 as a surface molecule expressed on the surface of the gastric stem cells and used as a marker for identification of the gastric cancer stem cells [39].

Also the negativity of the GSCs proved in this study was in line with the results of a previous study detected that the surface marker CD34 is expressed only on the surface of the haematopoietic cells as in the lymphoid tissue so used as a surface marker in the diagnosis of cases of leukemia [40].

Culturing the GSCs on DMEM-F12 supplemented by the human platelet lysate and $1 \%$ Penicillin-Streptomycin that improves the cell viability and proliferation was done in correlation with previous studies where DMEN-F12 has been used to culture the corneal stem cells derived from the corneal stroma [41] and the umbilical cord mesenchymal stem cells [42]. Enriching the culture medium with human platelet lysate was in line with the results of a previous sudy proved that human platelet lysate is very useful when added to the culture medium as it contains a high level of growth factors helping the proliferation of the cells also, the human platelet lysate replaced the fetal bovine serum (FBS) as a nuritive substance added to the culture of the stem cells to promote the proliferation of the cells [43]. The addition of $1 \%$ PenicillinStreptomycin antibiotics to the culture medium 
was done because the necessity to add these antibiotics to the cultur media was proved in the past to prevent the bacterial growth $[\mathbf{4 4 , 4 5 ]}$.

In this study, most of the GSCs became attached to the floor of the Petri dishes with spindle-shaped and polygonal morphology with numerous cytoplasmic processes with the formation of cell coloneis in the primary culture. These findings were in agrement with the results of studies done previously and proved that, the cultured stem cells show plastic adherent properties with the formation of cytoplasmic processes with the ability of the stem cells to become adherent to the plastic culture dishes with the formation of colonies with spindle shape during the first cultures $[46,47]$.

In the present study, the formation of clonies indicated the ability of the GSCs to proliferate and this was in correlation with the results of previous studies detected that, the culture of the stem cells derived from the gastric mucosa form colonies with small cell bodies and long cytoplasmic processes [48].

In the current study, the vital stain trypan blue that stains the dead cells with damaged cell membrane was used in agrement with previous studies to detect the number of the living and dead cells as it leaks through the intact cell membranes into inside the cells so, it stains the dead cells only [49]. The viability of the GSCs was more than $95 \%$ through the different passages and this finding was the same as the results of previous studies [50].

\section{Conclusion:}

According to the findings of this study, it is possible to isolate stem cells from the gastric mucosa then, these cells can proliferate when cultured on the suitable media that consists of DMEM-F12 enriched by FBS and supplemented by $1 \%$ penicillin/streptomycin to produce large number of gastric stem cells. The GSCs then can be characterized through their positivity against Nestin and CD44 antigens and negativity against CD34 antigen. The large number of the GSCs produced gives the hope of the possibility to use these cells in the cell therapy for treatment of some degenerative diseases.

\section{References}

1- ROZENBLATT-ROSEN O., STUBBINGTON M.J.T., REGEV A. and TEICHMANN S.A.: The Human Cell Atlas: from vision to reality. Nature, 550: 451-453, 2017.

2- ERTEN E.Y. and KOKKO H.: From zygote to a multicellular soma: Body size affects optimal growth strategies under cancer risk. Evolutionary Applications Journal, 13 (7): 1593-1604, 2020.
3- GAO X., NOWAK-IMIALEK M. and LIU P.: Establishment of porcine and human expanded potential stem cells. Nature Cell Biology Journal, 21: 687-699, 2019.

4- TUCH B.E.: Stem cells - a clinical update. Australian Family Physician, 35: 719-721, 2006.

5- BIEHL J.K. and RUSSELL B.: Introduction to Stem Cell Therapy. Cardiovasc. Nurs Journal, 24 (2): 98-105, 2009.

6- BARKER N., BARTFELD S. and CLEVERS H.: Tissueresident adult stem cell populations of rapidly selfrenewing organs. Stem Cell Journal, 7: 656-670, 2010.

7- ARNOLD K., SARKAR A., YRAM M.A., POLO J.M., BRONSON R., SENGUPTA S., SEANDEL M., GEIJSEN N. and HOCHEDLINGER K.: Sox2(+) adult stem and progenitor cells are important for tissue regeneration and survival of mice. Cell Stem Cell Journal, 9: 317-329, 2011.

8- BAILEY A.T., WEATHERBEEA1 TONGTONG CUI T. and ZERNICKA-GOETZAB M.: Modeling human embryo development with embryonic and extra-embryonic stem cells. Developmental Biology, 474: 91-99, 2021.

9- GURUSAMY N., ALSAYARI A., RAJASINGH S. and RAJASINGH J.: Adult Stem Cells for Regenerative Therapy. Progress in Molecular Biology and Translational Science, 160: 1-22, 2018.

10- YUZWA S.A., J. BORRETT M.J., INNES B.T., VORONOVA A., KETELA T., DAVID R. KAPLAN D.R., BADER G.D. and MILLER F.D.: Developmental Emergence of Adult Neural Stem Cells as Revealed by Single-Cell Transcriptional Profiling. Cell Reports, 21 (13): 39703986, 2017.

11- ANDRZEJEWSKA A., LUKOMSKA B. and JANOWSKI M.: Concise Review: Mesenchymal Stem Cells: From Roots to Boost. Stem Cells, 37 (7): 855-864, 2019.

12- LIOYD-LEWIS B., HARRIS O.B., WATSON C.J. and DAVIS F.M.: Mammary Stem Cells: Premise, Properties, and Perspectives. Trends in Cell Biology, 27 (8): 556$567,2017$.

13- BHARTIYA D. and ANAND S.: Effects of oncotherapy on testicular stem cells and niche. Molecular Human Reproduction, 23 (9): 654-655, 2017.

14- WEI Q. and FRENETTE P.S.: Niches for Hematopoietic Stem Cells and Their Progeny. Immunity, 48 (4): 632648, 2018.

15- YOSHIDA Y. and YAMANAKA S.: Induced Pluripotent Stem Cells 10 Years Later. Circulation Research: for Cardiac Applications, 120 (12): 1958-1968, 2017.

16- MARCUS A.J. and WOODBURY D.: Fetal stem cells from extra-embryonic tissues: Do not discard. Cellular and Molecular Medicine, 12 (3): 730-742, 2008.

17- WILSON R.L. and STEVENSON C.E.: Anatomy and Physiology of the Stomach. Shackelford's Surgery of the Alimentary Tract, 2 (8): 634-646, 2019.

18- BOSCHEE E.D., YAP J.Y.K. and TURNER J.M.: Prediction of esophageal and gastric histology by macroscopic diagnosis during upper endoscopy in pediatric celiac disease. World Journal of Gastroenterology, 23 (4): 646652, 2017.

19- SIGAL M., LOGAN C.Y., KAPALCZYNSKA M., MOLLENKOPF H.J., BERGER H., WIEDENMANN B., 
NUSSE R., AMIEVA M.R. and MEYER T.F.: Stromal $\mathrm{R}$-spondin orchestrates gastric epithelial stem cells and gland homeostasis. Nature Journal, 548: 451-455, 2017.

20- BARTFELD S. and KOO B.K.: Adult gastric stem cells and their niches. Rev. Dev. Biol., 6: 261, 2017.

21- CONNOR R.O. and DRISCOLL L.O.: Setting up a Cell Culture Laboratory. Cell Biology, 1: 5-11, 2006.

22- HENN A.D., DAROU S. and YERDEN R.: Scaling of massively parallel patient-specific cell cultures with a transportable conditioned cell culture chamber. Biochemical Engineering Journal, 132: 139-144, 2018.

23- KNIGHT E., MURRAY B., CARNACHAN R. and PRZYBORSKI S.: Polystyrene Scaffold Technology for Routine Three Dimensional Cell Culture. Methods in Molecular Biology, 695: 323-340, 2010.

24- MIAZZI F., SCHULZE H., ZHANG L., KALTOFEN S., HANSSON B.S. and WICHER D.: Low Ca2+ levels in the culture media support the heterologous expression of insect odorant receptor proteins in HEK cells. Neuroscience Methods Journal, 312 (15): 122-125, 2019.

25- TANCHAROEN W., AUNGSUCHAWAN S., POTHACHAROEN P., BUMROONGKIT K., PUANINTA C., PANGJAIDEE N., NARAKORNSAK S., MARKMEE R., LAOWANITWATTANA T. and THAOJAMNONG C.: Human platelet lysate as an alternative to fetal bovine serum for culture and endothelial differentiation of human amniotic fluid mesenchymal stem cells. Molecular Medicine Reports, 19 (6): 5123-5132, 2019.

26- HYUN S., KIM B., LIN D., HYUN S., YOON S.S. and SEO J.: The effects of gentamicin and penicillin / streptomycin on the electrophysiology of human induced pluripotent stem cell-derived cardiomyocytes in manual patch clamp and multi-electrode array system. Pharmacological and Toxicological Methods Journal, 91: 1-6, 2018.

27- TACHIBANA K.: N-cadherin-mediated aggregate formation; cell detachment by Trypsin-EDTA loses N-cadherin and delays aggregate formation. Biochemical and Biophysical Research Communications, 516 (2): 414-418, 2019.

28- TENG X., CHEN L., CHEN W., YANG J., YANG Z. and SHEN Z.: Mesenchymal Stem Cell-Derived Exosomes Improve the Microenvironment of Infarcted Myocardium Contributing to Angiogenesis and Anti-Inflammation. Cellular Physiology Biochemistry, 37: 2415-2424, 2015.

29- KHURANA S.S., RIEHL T.E., MOORE B.D., RICHARD P., STENSON W.F. and MILLS J.C.: The Hyaluronic Acid Receptor CD44 Coordinates Normal and Metaplastic Gastric Epithelial Progenitor Cell Proliferation. Biological Chemistry Journal, 288 (22): 16085-16097, 2013.

30- DHINGRA S., FENG W., BROWN R., ZHOU Z., KHOURY T., ZHANG R. and TAN D.: Clinicopathologic significance of putative stem cell markers, CD44 and nestin, in gastric adenocarcinoma. International Journal of Clinical and Experimental Pathology, 4 (8): 733-741, 2011.

31- MUSHAHARY D., SPITTLER A., KASPER C., WEBER V. and CHARWAT V.: Isolation, cultivation, and characterization of human mesenchymal stem cells. Cytometry Journal of Quantitative Cell Science, 93 (1): 19-31, 2018.
32- GARCIA M., CHOMEL J., MUSTAPHA P., TRAN C.T., GARNIER M., PARIS I., QUELLARD N., GODET J., CREMNITER J., BENNACEUR-GRISCELLI A., LECRON J., TURHAN A.G., BURUCOA C. and BODET C.: In vitro culture and phenotypic and molecular characterization of gastric stem cells from human stomach. Helicobacter, 22 (2): 12351, 2017.

33- YANG Y., WANG S., HUNG H., CHANG C., WU I., HUANG Y., LIN T., TSAI J., CHEN A., KUO F., WANG W. and WU D.: Isolation and characterization of human gastric cell lines with stem cell phenotypes. Gastroenterology and Hepatology Journal, 22 (9): 1460-1468, 2007.

34- HU Y. and LI Y.V.: Expression of SSEA-4 and Oct-4 from somatic cells in primary mouse gastric cell culture induced by brief strong acid. Molecular and Cellular Biochemistry, 476: 2813-2821, 2021.

35- AVELAR-FREITAS B.A., ALMEIDA V.G., PINTO M.C.X., MOURAO F.A.G., MASSENSINI A.R., MARTINS-FILHO O.A., ROCHA-VIEIRA E. and G.E.A. BRITO-MELO GEA: Trypan blue exclusion assay by flow cytometry. Brazilian Journal of Medical and Biological Research, 47 (4): 1414-1431, 2014.

36- BARTFELD S., BAYRAM T., WETERING M., HUCH M., BEGTHEL H., KUJALA P., VRIES R., PETERS P.J. and CLEVERS H.: In Vitro Expansion of Human Gastric Epithelial Stem Cells and Their Responses to Bacterial Infection. Gastroenterology, 148 (1): 126-136, 2015.

37- BARKER N., MERITXELL HUCH M., KUJALA P., WETERING M., SATO T., STANGE D., BEGTHEL H., BORN M.K., DANENBERG E., BRINK S., KORVING J., PETERS P.J., WRIGHT N., POULSOM R. and CLEVERS H.: Lgr5+ve Stem Cells Drive Self-Renewal in the Stomach and Build Long-Lived Gastric Units In Vitro. Cell Stem Cell, 6 (1): 25-36, 2010.

38- LIU J., CHEN W., JI X., ZHENG W., HAN W. and AN J.: Correlation of Overexpression of Nestin with Expression of Epithelial-Mesenchymal Transition-Related Proteins in Gastric Adenocarcinoma. Asian Pacific Journal of Cancer Prevention, 16 (7): 2777-2783, 2015.

39- ZAVROS Y.: Initiation and Maintenance of Gastric Cancer: A Focus on CD44 Variant Isoforms and Cancer Stem Cells. Cellular and Molecular Gastroenterology and Hepatology, 4 (1): 55-63, 2017.

40- KIM W. and RYU C.: Cancer stem cell surface markers on normal stem cells. BMB Reports, 50 (6): 285-298, 2017.

41- SIDNEY L.E., BRANCH M.J., DUA H.S. and HOPKINSON A.: Effect of culture medium on propagation and phenotype of corneal stroma-derived stem cells. Cytotherapy, 17 (12): 1706-1722, 2015.

42- PHAM P.H., TRUONG N.C., LE P.T., TRAN T.D., VU N.B., BUI K.H. and PHAN N.K.: Isolation and proliferation of umbilical cord tissue derived mesenchymal stem cells for clinical applications. Cell and Tissue Banking, 17: 289-302, 2016..

43- COWPER M, FRAZIER T., WU X., CURLEY J.L., MA M.H., MOHIUDDIN O.A., DIETRICH M., McCARTHY M., BUKOWSKA J. and GIMBLE J.M.: Human Platelet Lysate as a Functional Substitute for Fetal Bovine Serum in the Culture of Human Adipose Derived Stromal Stem Cells. Cell, 8 (7): 724, 2019. 
44- LIU J., HUANG Z., YANG L., WANG X., WANG S., LI C., LIU Y., CHENG Y., WANG B., SANG X., HE X., WANG C., LIU T., LIU C., JIN L., LIU C., ZHANG X., WANG L. and ZHICHONG WANG Z.: Embryonic Stem Cells Modulate the Cancer-Permissive Microenvironment of Human Uveal Melanoma. Theranostics, 9 (16): 4764$4778,2019$.

45- SATO T., KATAGIRI K., KUBOTA Y. and OGAWA T.: In vitro sperm production from mouse spermatogonial stem cell lines using an organ culture method. Nature Protocols, 8: 2098-2104, 2013

46- TAKAISHI S., OKUMURA T. and WANG T.C.: Gastric Cancer Stem Cells. Clinical Oncology Journal, 26 (17): 2876-2882, 2008.

47- KATANO T., OOTANIB A., MIZOSHITA T., TANIDA S., TSUKAMOTO H., OZEKI K., EBI M., MORI Y., KATAOKA H., KAMIYA T., TODA S. and JOH T.:
Establishment of a long-term three-dimensional primary culture of mouse glandular stomach epithelial cells within the stem cell niche. Biochemical and Biophysical Research Communications, 432 (4): 558-563, 2013.

48- KIM G., GINGA N. and TAKAYAMA S.: Integration of Sensors in Gastrointestinal Organoid Culture for Biological Analysis. Cellular and Molecular Gastroenterology and Hepatology, 6 (1): 123-131, 2018.

49- LEBEAU P.F., CHEN J., BAYUN J.H., PLATKO K. and AUSTIN R.C.: The trypan blue cellular debris assay: A novel low-cost method for the rapid quantification of cell death. Methods, 6: 1174-1180, 2019.

50- JOKSIC G., TRICKOVIC J.F., MICIC M., JOKSIC I., SOBOT A.V. and DEMAJO M.: Optimization of the method for isolation of epithelial cells from the nonglandular part of the rat stomach for flow cytometry. Veterinarski Archive, 90 (5): 517-525, 2020.

\section{فصل وزراعة الخلايا الجذعيلة من الغشاء المخاطى المعدى الجياء

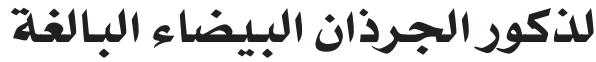

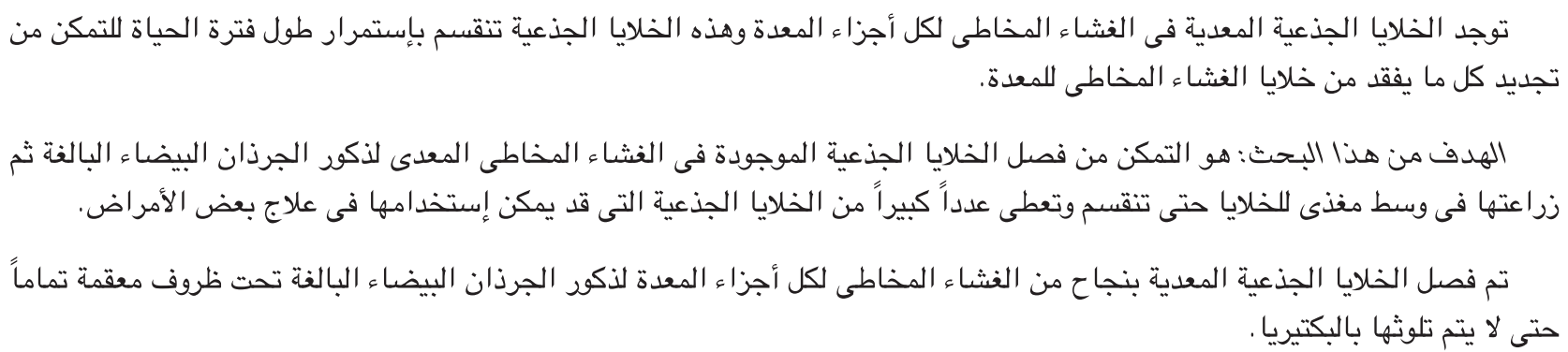

الخلايا الجذعية المعدية التى تم فصلها زرعت فى وسط مناسب وهو مزيج النسر المتوسط المغذى المعدل من دوليكو F-12 مضافاً إليه

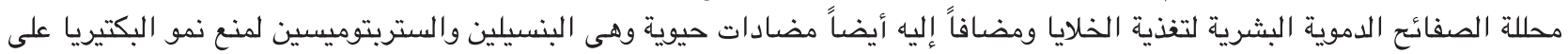
وسط مزرعة الخلايا فانقسمت الخلايا عدة مرات وأعطت عدداً كبيراً متلاق ومستعمرات من الخلايا الجذعية المعدية.

عندما بلغ تلاقى الخلايا الجذعية المعدية فى المزرعة أكثر من .^٪ تم فصل هذه الخلايا وعمل مزارع ثانوية تم تتميتها بنفس طريقة المزرعة

التعرف على الخلايا الجذعية المعدية تم عن طريق العمليات الكيميائية المناعية حيث كانت إيجابية مع الأجسام المضادة وحيدة النسيلة المضادة لكل من CD44 ونستن.

نتائج البحث: الخلايا الجذعية من الغشاء المخاطى للمعدة يمكن أن تفصل بنجاح من معدة ذكور الجرذان البيضاء البالغة ثم بعد ذلك يمكن

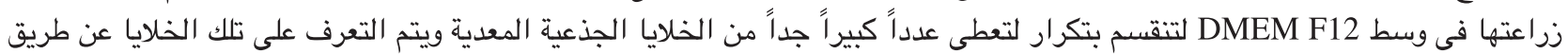
العمليات الكيميائية لأنها تككن إيجابية وتصبخ عند إضفة الأجسام المضادة وحيدة النسيلة المضادة لـ CD44 ونستن بينما تكون سلبية ولا 